تأثير هنهج تدريبي في بعض المتغيرات الوظيفيةو أنجاز م0 م عدو للطلاب -بمث تهريبي- على عينة من طابة

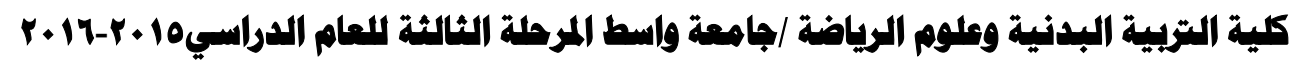

أ.م.د. غفار سعد عيسى/ كلية التربية الرباضية/ جامعة واسط

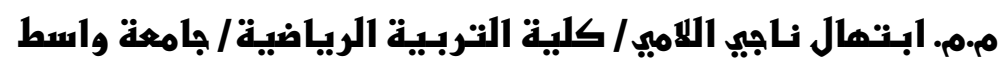
أهداف البحث اـ التعرف على التطور الحاصل في النظام الفوسفاجيني من خلال انجاز عدو •ـ متر وعودة الثفاء وعدد : مرات التنفس . r- التعرف على التطور الحاصل في نشاط إنزيم كرياتين كاينيز ( CK) . ـ أن عدو المسـافات القصـيرة إحدى الفعاليـات اللاهو ائيسة ، والتي يتم تحقيـق الانجـاز فيهـا في ظل غيـاب الأوكسجين من خلال اعتمادهـا على نظـام إنتاج الطاقة اللاهو ائية ــ وهنـا تكمن أهميـة البحث حول تطوير

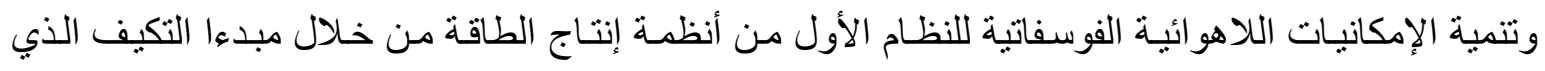
يعتمد على إحداث نقص في كمية الراحة اللازمة لإعادة تكوين الطاقة اللازمة من كرياتين الفوسفات و التي يعتمد عليها اللاعب في أل ( ب-. ( ) ثو اني الأولى من زمن الجهد المطلوب ، (( أن العلاقة بين مفهوم التدريب الرياضي وبين حقيقة قدرة الكائن الحي على التكيف ، حيث تعد العملية التدريبية هنـا كميـة الجهد

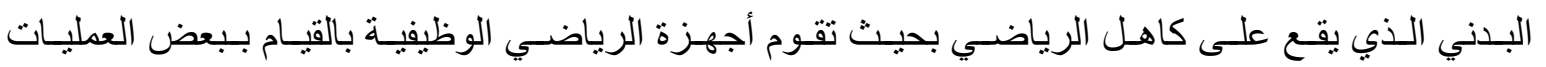
الفسيولوجية والكيميائية هدفها الحصول على المناعة للتصدي لهذا الحمل البدني في حال تكراره ومفهوم المناعة من وجهة نظر علم التدريب الرياضي هي ارتفاع المستوى الذي نم الوصول إليه )) .

\title{
فروض البمث : ان
}

ا- هناك فروق ذات دلالة إحصائية في انجاز عدو •0 متر و عودة الثفاء و عدد مرات التنفس بين العينتين الضابطة والتجريبية ولصالح العينة التجريبية . r- هناك فروق ذات دلالة إحصائية في نشاط إنزيم كرياتين كاينيز (CK) بين العينتين الضـابطة والتجريبية ولصالح العينة التجريبية . ع ـ الاستنتاجات :- من خلال تحليل النتائج ومناقتنها توصل الباحث إلى الاستنتاجات الآتية :

\section{أولا - المجموعة التجريبية :}

ا ـ ظهور فرق معنوي في زمن اختبار عدو •0 م لعدد مر ات التنفس في الراحة و عدد مرات التنفس بعد

الجهد مما يدل على فاعلية برنامج نقص الفوسفاجين .

r- عدم ظهور فرق معنوي لمعدل ضربات النبض في الر احة مما يدل عدم فاعلية برنامج الفوسفاجين . r- ظهور فرق معنوي في الخمس دقائق الأولى بعد الجهد البدني مما يدل على فاعلية نقص الفوسفاجين . عـ ظهور فرق معنوي في زيادة نشاط كرياتين كاينيز بسبب تأثير برنامج نقص الفوسفاجين .

\section{ثانيًاً : المبموعة الضابطة}

1 - عدم ظهور فرق معنوي لزمن اختبار عدو .0 م مما يدل عدم فاعلية برنامج المجموعة الضابطة . 
r ـ ظهور فرق معنوي في عدد مـرات التنفس في وقت الراحة ممـا يـل على فاعلية برنـامج المجموعـة الضابطة تجاه هذا المتغير .

זـ عدم ظهور فرق معنوي في عدد مرات التنفس في الاقيقة بعد الجهد و في وقت الر احة مما يدل على عدم تكيف المجمو عة الضابطة .

ـ ـ عدم ظهور فرق معنوي في عدد مرات النبض للثلاث دقائق الأولى بعد الجهد مما يدل على عدم تكيف المجمو عة الضابطة .

هـ ظهور فرق معنوي في عدد مرات ( النبض في الدقيقة ) للاقيقتين الر ابعـة والخامسـة بعد الجهد مدـا يدل على تكيف المجموعة الضابطة لهذه الفترة من الجهر . 7ـ عدم ظهور فرق معنوي في نشاط إنزيم كرياتين كاينيز ( CK) مما يدل على عدم فاعلية البرنـامج لهذا

ABSTRACT

Effect of $A$ training program on some functional variables in the completion of $50 \mathrm{~m}$ ran

BY :KAFFAR SAAD ISA AND IBTIHAL NAJI AL_LAMI

COLLEGE OF PHYSICAL EDUCATION AND SPORTS SCIENCE // WASIT UNIVERSITY.

Research goals :-

1. recognize the evolution in Alphusvegene system through the completion ran 50 meters and the return of healing

And the number of times breathing.

2. recognize the evolution in the activity of the enzyme creatineKanez (CK).

- That ran short distances an event anaerobic, in which achievement is achieved in the absence of oxygen, through its reliance on anaerobic energy production system. Here lies the importance of research, about the development potential of anaerobic phosphate, the first system of energy production systems, through the principle of adaptation, which relies on creating a shortage in the amount of needed rest, to reconfigure the power needed from creatine phosphate, and relied upon by the player at the (3-10) the first seconds, into the desired voltage, ((that the relationship between the concept of sports training and the fact that the organism to adapt to the capacity, in terms of the training process is here, the amount of physical effort, which is located on the shoulders of sports so that the sports equipment functional doing some physiological processes, Chemical and aim to get immune to address this physical pregnancy, in case of repeated and the concept of immunity from the point of view of sports training, is the high level that has been reached)).

Research hypotheses :

1. There were statistically significant in completing ran $\mathbf{5 0}$ meters and the return of healing differences, and the number of times between the two samples of breath control, and experimental and the experimental sample.

2. There were statistically significant differences in the activity of the enzyme creatineKanez (CK), between the two samples control, the experimental and the experimental sample. 
أصبح التدريب الرياضي عملية لها الدور الكبير والهام في المجتمعات المتحضرة في مجال التنـافس لمختلف الأنشطة و الفعاليات الرياضية بعد الإيمان بـه كوسيلة هامـة لزيادة كفاءة ومقدرة الرياضيين البدنيـة و ألمهاريةو الخططية من خلال اعتماده على المعارف و المعلومات ومو اكبة التطور العلمي و التكنولوجي لهذه المعـارف و استخدامه التقنيـة العلميـة والتكنولوجيـة لهذهـ المعـارف واستخدامه التقنيـة العلميـة لعلوم الطب ، و التشريح و البايو ميكانيك و التعلم الحركي وتحليل أجزاء الحركات المختلفة للتعرف على مواضيع الخلل في

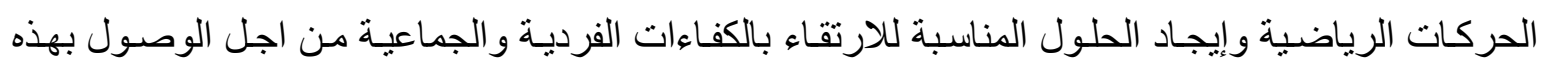
القدرات نحو مستوى أفضل.

و عدو المسافات القصيرة هي إحدى الفعاليات الرياضية التي كان لها نصيبها الكبير في هذا التطور العلمي و التكنولوجي. وقد سلك مدربو العـاب السـاحة و الميدان العديد من الطرق والوسـائل العلميـة المختلفة للتنريب الرياضي وفي صراع مع الزمن باعتمـادهم العلوم المختلفة من اجل الوصول إلى تطوير عدائيهم لأقل جزء من الثانية من خلال تطوير إمكانياتهم الفسيولوجية والحركية . و عدو المسـافات القصيرة إحدى الفعاليات اللاهوائية ، والتي يتم تحقيق الانجاز فيها في ظل غياب

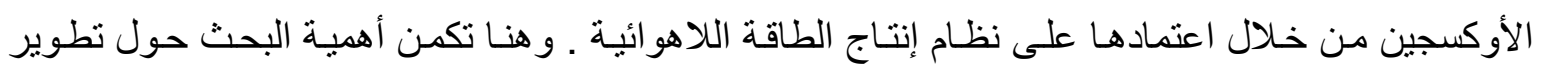

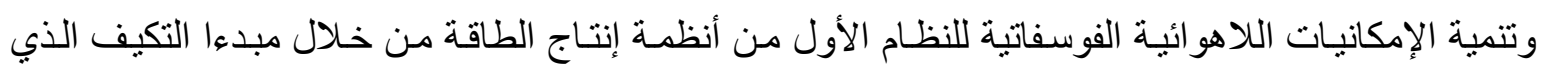
يعتمد على إحداث نقص في كمية الراحة اللازمة لإعادة تكوين الطاقة اللازمة من كرياتين الفوسفات و التي يعتمد عليها اللاعب في أل ( r-. ( ) ثواني الأولى من زمن الجهد المطلوب ، ((أن العلاقة بين مفهوم التدريب الرياضي وبين حقيقة قدرة الكائن الحي على التكيف ، حيث تعد العملية التدريبية هنـا كمية الجهد

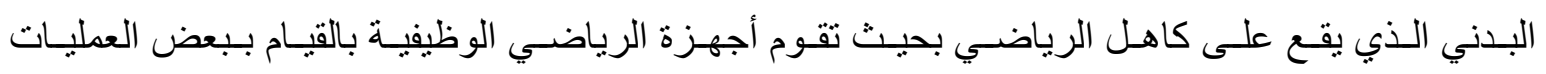
الفسيولوجية والكيميائية هدفها الحصول على المناعة للتصدي لهذا الحمل البدني في حال تكر اره ومفهوم المناعة من وجهة نظر علم التدريب الرياضي هي ارتفاع المستوى الذي تم الوصول إليه)) 1. تطرقت اغلب المصسادر العلميـة والتي كتبت عن موضـوع تنميـة وتطـوير السـرعة ومدى تأثيرهـا

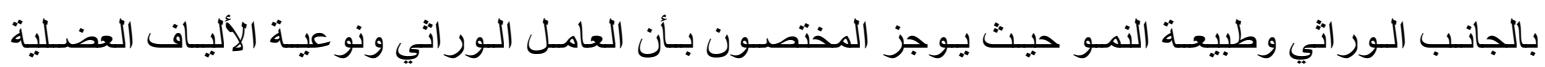
و العصبية لهما التأثير الكبير في مميزات العدو السريع (( أن هناك عوامل عديدة تتأثر بها السرعة ، منهـ القدرة على الاسترخاء و المقاييس الانثروبومترية والتو افق العضلي العصبي ونوعية الألياف العضلية والقدرة . اللاهو ائية ()

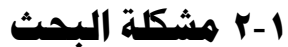

من خلال منابعة الباحثين لمختلف الطرق و الوسـائل التدريبية بالعـاب السـاحة والميدان لاحظـا ان عدو المسافات القصيرة هو إحدى الفعاليات اللاهو ائية ، والتي يتم تحقيق الانجاز فيها في ظل غياب الأوكسجين 
من خلال اعتمادها على نظام إنتاج الطاقة اللاهو ائية من خـلال مبدءا التكيف الذي يعتمد على إحداث نقص في كمية الراحة اللازمة لإعادة تكوين الطاقة اللازمة من كرياتين الفوسفات والتي يعتمد عليها اللاعب في أل

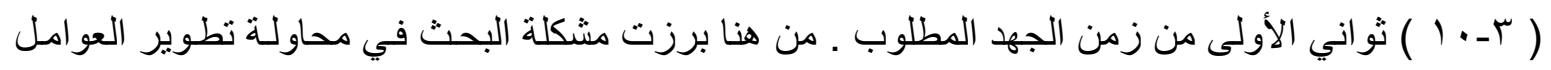

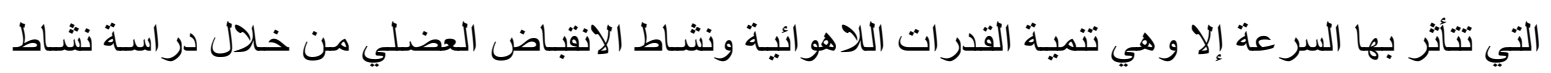
أنزيم ( كرياتين كاينيز ) الذي يؤدي إلى سرعة تكسير أواصر (PC) لتوليد الطاقة ، وقدرة اللاعب على

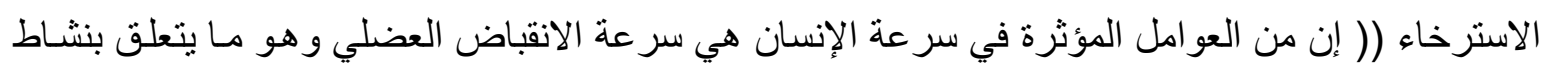
إنزيم (كرياتين كاينيز ) وكذلك القدرة على الاسترخاء وهو مـا يتعلق بعودة الثفاء وأخير التميـة القدرات

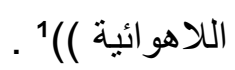

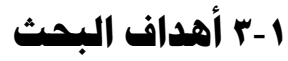

اـ التعرف على التطور الحاصل في النظام الفوسفاجيني من خلال انجاز عدو •0 متر وعودة الثفاء وعدد

$$
\text { مرات التنفس . }
$$

r- التعرف على التطور الحاصل في نشاط إنزيم كرياتين كاينيز (CK) .

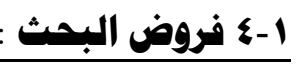

1- هناك فروق ذات دلالة إحصائية في انجاز عدو •. متر وعودة الثفاءو و عدد مرات التنفس بين العينتين الضابطة والتجريبية ولصالح العينة التجريبية .

r- هناك فروق ذات دلالة إحصائية في نشاط إنزيم كرياتين كاينيز (CK) بين العينتين الضـابطة والتجريبية ولصالح العينة التجريبية .

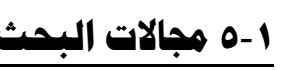

1-1 المجال البشري : طلبة كلية التربية البدنية وعلوم الرياضة /جامعة واسط / المرحلة الثالثة .

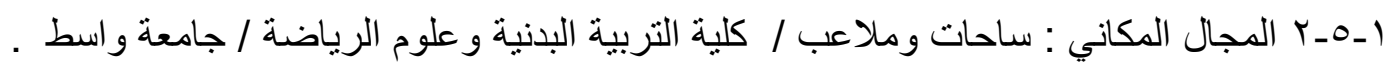

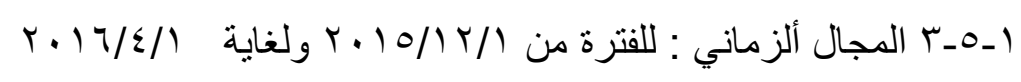

\section{منهج البحث وإجراءاته الميدانية.}

r-1 منهج البحث : استخدمت الباحثان المنهج التجريبي لملائمته لطبيعة البحث .

r - reينة البحث: اجري البحث على عينة عمديه تكونت من ؟r طالبا من طلاب كلية التربية البدنية وعلوم

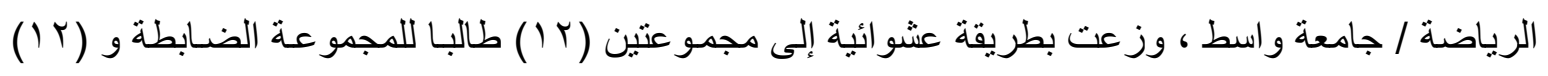

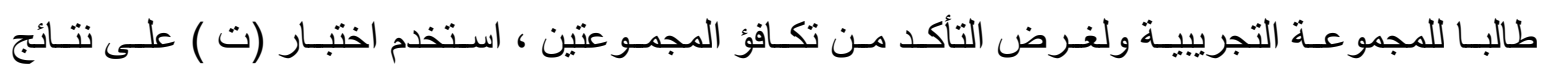
المجمو عتين في الاختبـار القبلي عدو •.0 متر والطول و الوزن ، ويوضـح الجدول (Y) المعـالم الاحصـائية للمتغير ات التي استخدمت في التأكيد من تكافؤ مجمو عات البحث . 
جدول (ץ) يوضح التكافؤ للعينتين الضابطة والتجريبية

\begin{tabular}{|c|c|c|c|c|c|c|c|}
\hline \multirow{2}{*}{ الاحصائية } & \multirow{2}{*}{ قالجدولة ت } & \multirow{2}{*}{ قاليمتسبة ت } & \multicolumn{2}{|r|}{ التجريبية" } & \multicolumn{2}{|r|}{ |الضابطة } & \multirow[t]{2}{*}{ |العينة } \\
\hline & & & $\varepsilon \pm$ & سـ & $\varepsilon \pm$ & س- & \\
\hline غير مغنوي & $r, r 4$ & $\cdot, 07$ & $\varepsilon, \wedge r$ & $19 V, Y 0$ & 0,94 & $199, \wedge \mathrm{V}$ & الطول سم \\
\hline غير معنوي & & $\cdot, \leqslant \wedge$ & $\cdot, 01$ & $T V, r v$ & $\cdot, 04$ & IV,O & العمر سنة \\
\hline غير معنوي & & $\cdot, \leqslant Y$ & $7, Y 1$ & $\Delta \wedge, 0$ & $\cdot, r 1$ & $\theta V, \theta$ & الوزن كفم \\
\hline غير معنوي & & $\cdot, \leqslant \mathrm{V}$ & $\cdot, 0 \wedge$ & $7, \leqslant 0$ & $\cdot, r \leqslant$ & $7, r \varepsilon$ & زمن عدا. \\
\hline
\end{tabular}

قيمة (ت) الجدولية إمام درجة حرية (ن- ( ) وعند مستوى خطاء ه •,

r-r الأجهزة والأدوات المستخدمة في البحث .

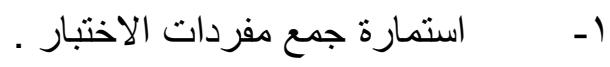

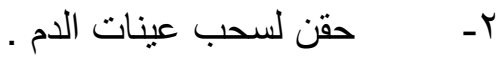

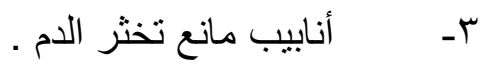

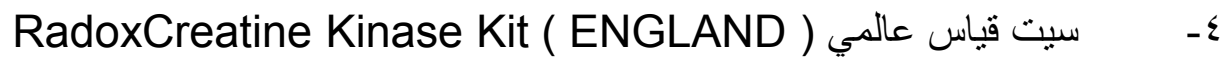

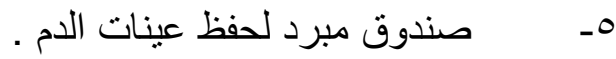

7- مسطرة لقياس الطول البدني .

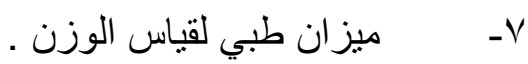

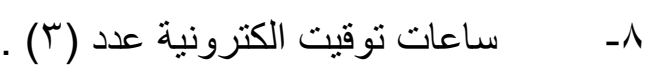

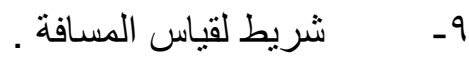

• 1 - جهاز سنترفيوج لفصل مصل الدم . -

r- (التجربة الاستطلاعية .

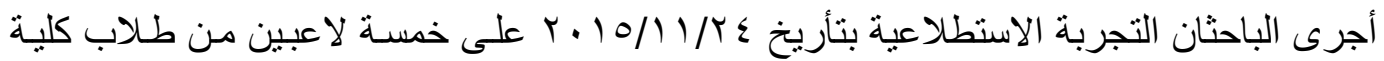

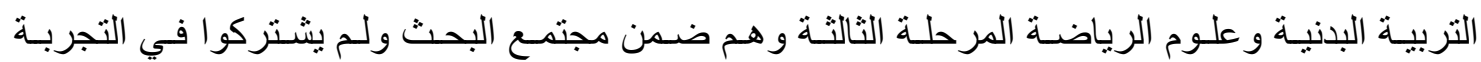

الرئيسية وتم اختيار هم عشوائيا وكان هدف الباحثان للتجربة الاستطلاعية هو :

1 التعرف على إمكانية العينة من جر اء الاختبار .

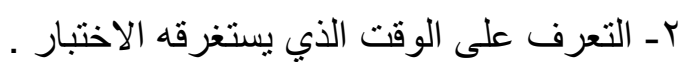

r- التعرف على إمكانية الفريق المساعد (*) من سحب عينات الدم وحساب زمن عودة الثفاء للخمس دقائق

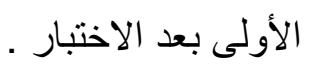

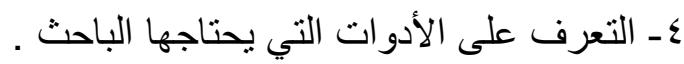

هـ التعرف على المعوقات التي قد تواجه الباحث إثناء إجر اء الاختبار . 
بـ - ب الاختبار ات والقياسات

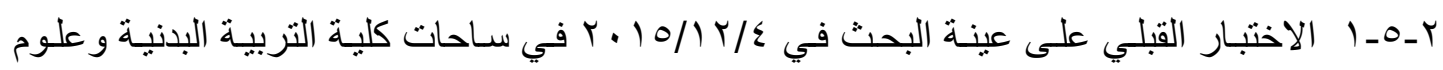

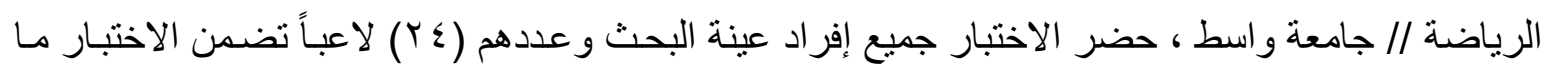
يلي : -

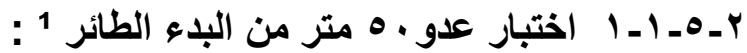

تم اختبار عينتي البحث ( الضابطة والتجريبية ) اختبار عدو •0 متر من البدء الطائر وحسب الزمن

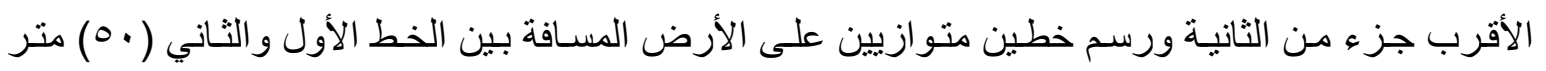
و عند سماع إثـارة البدء يقوم اللاعب بالعدو من على بعد (10) متر عن الخط الأول ويحسب الزمن ابتداء من الخط الأول إلى نهاية الخط الثاني ويسجل المختبر زمن ( • ) متر التي قطعها وتم احتساب الزمن يدوياً r-l-0-r تم سـب عينات من الدم بمقدار (ع) سمّ من الوريد العضدي لكل لاعب بعد إجراء اختبار عدو

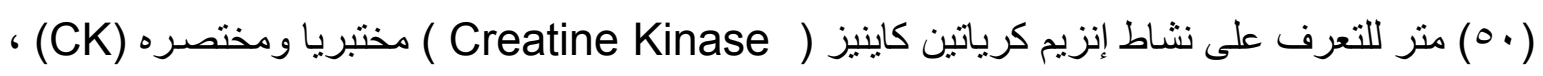

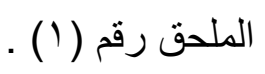

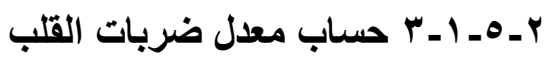

تم حساب معدل ضربات القلب في ظروف الراحة وكذلك حسابه بعد الدقيقة الأولى و الثانية و الثالثة و الرابعة والخامسة للتعرف على عودة الثفاء خلال الخمس دقائق الأولى بعد الجهر .

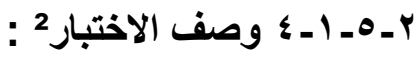

تم حساب عدد نبضات القلب عن طريق تحسس النبض فوق الثريان السباتي في العنق وهو يقع عند

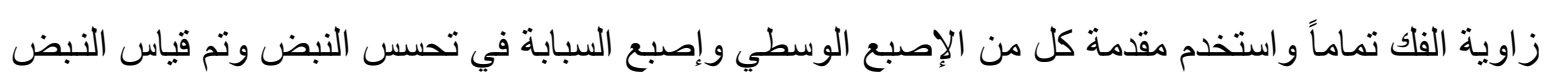

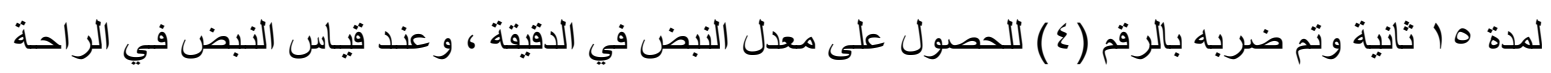

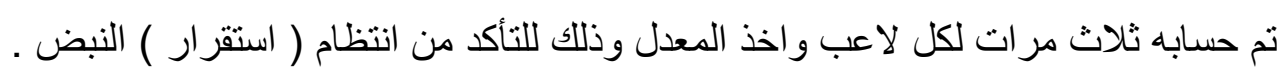

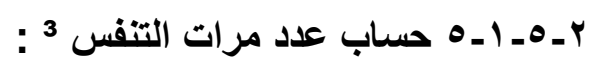
تم حساب عدد مرات التنفس قبل الجهد وبعد الجهد للعينتين الضـابطة والتجريبية عن طريق حساب عدد مرات الثهيق و الزفير مع عدم إخبار اللاعب بالاختبار .

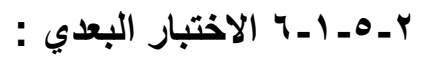

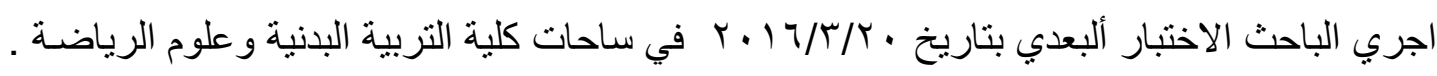
وحضر الاختبار (7 ( ) لاعباً ، (^) لاعبين لكل مجموعة ( الضـابطة والتجريبية ) وقد استبعد الباحث ( ع ) ) لكل مجموعـة لعـدم التـز امهم بالبرنـامج التدريبي وجرى الاختبـار تحت نفس الظـروف الزمانيـة والمكانيـة للاختبار القبلي و على نفس الاختبار ات والقياسات وسحب عينات الدم التي جرت في الاختبار القبلي 


\section{ب- البر البنامج التدريبي :-}

قام الباحثنان بأعداد برنـامج تدريبي شمل ( ع r ) وحدة تدرييـة تم تطبيقها على عينة البحث خـلال (^)أسابيع بو اقع ثلاث وحدات تدريبية في الأسبوع وبمعدل ( مان ) دقيقة للوحدة التدريبية (انظر ملحق رقم r)، وقد نم عرض البرنامج على مجموعة من الخبر اء والمختصين في مجال التدريب الرياضسي وقد تم تنفيذ

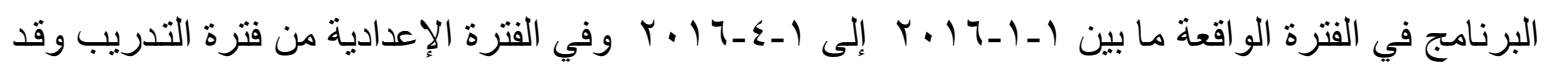
تم تتفيذ البرنـامج على العينتين الضـابطة والتجرييية بنفس ( الأزمنـة والتكرار ات ) مـع اختلاف في زمـن

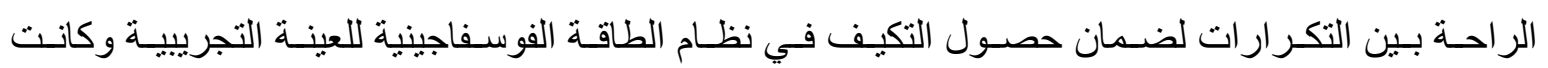
مواصفات البرنامج هي عن طريق عدو كل ثـلاث لاعبين سوية لضمان العدو بالثدة القصوى ويتم رجوع اللاعبين مشيا ، ويتم حساب النبض من قبل فريق العمل المساعد ولمدة ( 1 ) ثانية يتم ضربها × ـ للتأكد

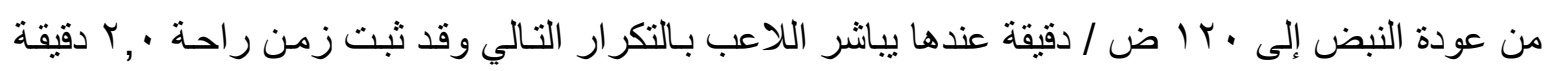
بين التكرارات في الأسبوع الأول وهكذا تم حساب النبض في الأسبوع الثاني وتم تنزيل فترة الراحة البينية بين التكرارات إلى ( 0 ؛ , ) دقيقة للأسبوع الثاني واستمر العمل بهذه الطريقة عن طريق تنزيل فترة الراحة البينية بين التكرارات ( • () ثانية كل أسبوع لضمان حصول التكيف في الإمكانيات الفوسفاتية في أعادة أنتاج

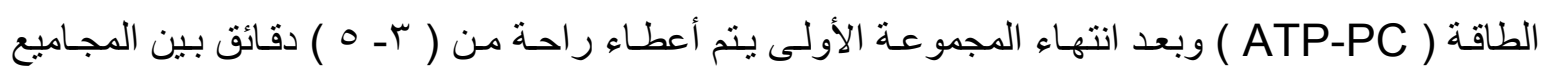
لضمان عدم تر اكم حامض أللبنيك و عدم الانتقال إلى نظـام أنتاج الطاقة ( ATP - LA ) بعدها ينت تكرار المجمو عة الثانية و هكذا لنهاية البرنامج الموضح في الملحق (r) . أما المجمو عة الضابطة فقد تدربت بنفس الطريقة لركض التكرار ات مع الاختلاف في زمن الراحة البينية بإعطائهم (ب) دقائق بين التكرارات و ( بـه ) دقائق بين المجاميع .

$$
\text { أما محتويات البرنامج فهي :- }
$$

استغرق البرنامج (^) أسابيع بو اقع ثلاث وحدات تدريبية في الأسبوع . عدد الوحدات الكلية للبرنامج التدريبي ( \& ب وحدة ) . زمن الوحدة التدريية الواحدة ( .0 دقيقة ) . مجموع وقت التدريب الكلي ( . ب ا دقيقة ) . مجموع وقت الجزء التمهيدي ( • •ـء دقيقة ) . مجموع وقت الجزء الرئيسي ( • مـ دقيقة ) .

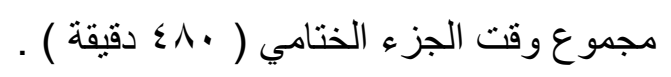

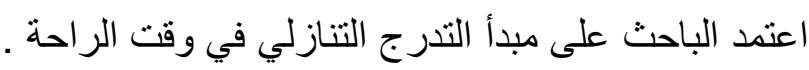
ـ اعتمد الباحثنان على التـدرج في صـعوبة البرنـامج مـع الإقـلال مـن فترة استعادة الثـفاء ، وتحكم

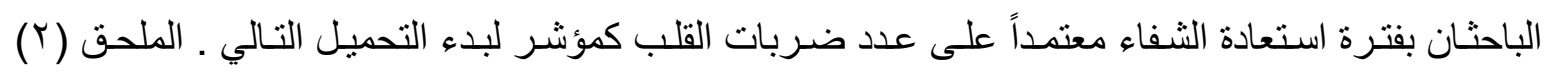
نموذج لوحدة تدريبية واحدة 


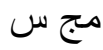

$$
\text { الوسط الحسابي }
$$

$\dot{v}$

$$
\text { الانحر اف المعياري = }
$$

r- عرض النتائج وتحليلها ومناقشتها

ץ- 1 عرض نتائج الاختبارين القبلي والبعدي للمجموعة التجريبية لزمن عدو • ه متر.

\begin{tabular}{|c|c|c|c|c|c|c|c|}
\hline \multirow{2}{*}{ الاحصائية } & \multirow{2}{*}{ قالجيمة ت } & \multirow{2}{*}{ قالمتسبة ت } & \multicolumn{2}{|c|}{ الاختبّار ألبعدي } & \multicolumn{2}{|c|}{ الاختبار القبلي } & / الاختبار \\
\hline & & & $\varepsilon \pm$ & س- س ( س & $\varepsilon \pm$ & س- - س & \\
\hline مغنوي & $r, r^{4}$ & $r, 90$ & $\cdot, 11$ & $0, \wedge$. & $\cdot, 01$ & $7, \leqslant 0$ & زممن عدو \\
\hline
\end{tabular}

جدول (با)يوضح المعالم الاحصائية للاختبارين القبلي والبعدي لزمن عدو (• ) متر للمجموعة التجريبية

* قيمة (ت) الجدولية أمام درجة حرية (ن- 1 ) وعند مستوى خطاء ه •, •

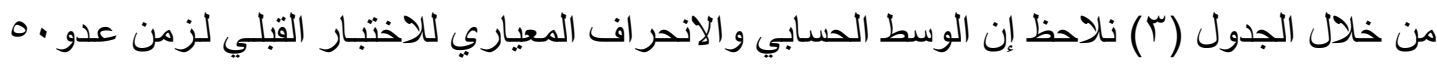

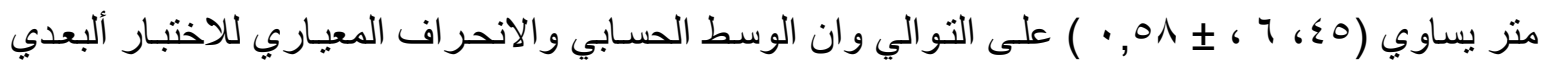

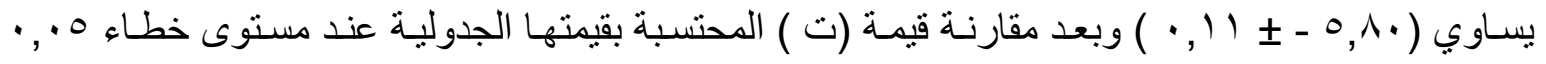
ودرجـة حريـة (V) نلاحظ إن قيمـة (ت) المحتسبة اكبر مـن القيمـة الجدوليـة وهذا الفرق معنوي ولصـالح الاختبار ألبعدي مما يدل على فعالية البرنامج اللاهو ائي لتطوير الإمكانيات الفوسفاتية لانجاز عدو ( •0) متر لعينة البحث التجرييية و التي طبق عليها البرنـامج الفوسفاتي اللاهو ائي(( يمكن تنميـة الإمكانيات الفوسفاتية اللاهو ائية بدون لاكتات ويعني ( ATP-CP ) بالتدريب لفترات متعاقبة من العمل و الر احة وبشدة عالية جداً

$$
\text { و لا تزيد عن ( • ( ) ثوان لكي يسمح بإعادة مخزون الطاقة في العضلات))1 . }
$$

وترى الباحثان إن الإمكانيـات الفوسفاتية اللاهو ائية للعينـة التجرييية و التي خضعت للتدريبات بالثدة العالية وضمن الحدود الطبيعية لفترة تطوير هذه الإمكانيات مما أثر على زمن انجاز عدو .0 متر .

\begin{tabular}{|c|c|c|c|c|c|c|c|}
\hline \multirow{2}{*}{ الاحصائية } & \multirow{2}{*}{ قالجدولية } & \multirow{2}{*}{ قالمتسة ت } & \multicolumn{2}{|c|}{ الاختبار ألبعدي } & \multicolumn{2}{|c|}{ الاختبار القبلي } & \multirow{2}{*}{ 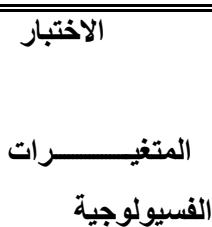 } \\
\hline & & & $\varepsilon \pm$ & س- - م- & $\varepsilon \pm$ & 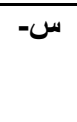 & \\
\hline
\end{tabular}

r-r عرض نتائج الاختبارين القبلي والبعدي للمجموعة التجريبية لبعض المتغيرات الفسيولوجية وأنزيم (CK) جدول ( ) )يوضح المعالم الاحصائية للاختبارين القبلي والبعدي للمتغيرات الفسيولوجية للمجموعة التجريبية 


\begin{tabular}{|c|c|c|c|c|c|c|c|}
\hline معنوي & $Y, r q$ & 0,7 & I,IY & $10,1 Y$ & $1, \cdot 9$ & $\mid \Lambda, r v$ & الراحة م/د في \\
\hline مغنوي & & $r, \cdot 0$ & $7, \& 1$ & Vy & $V, Y T$ & $\Lambda \Psi, \theta$ & ض/النبض في الراحة \\
\hline
\end{tabular}

قيمة ( ت) الجدولية إمام درجة حرية (ن- () وعند مستوى خطاء ه •, · .

يبين الجدول (ع ) الأوساط الحسابية والانحر افات المعيارية للاختبار القبلي لمتغير عدد مرات التنفس

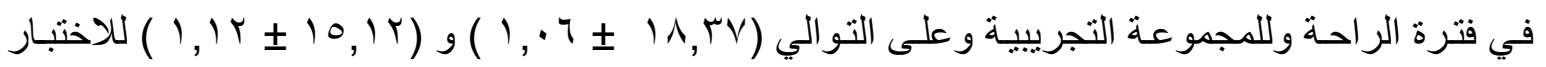

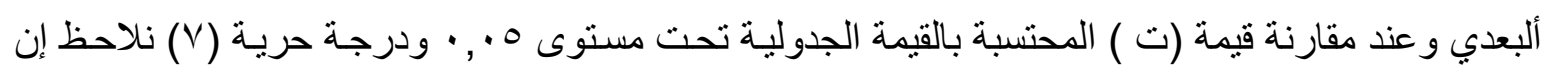
القيمـة المحتسبة اكبر من القيمـة الجدولية ممـا يدل على معنويـة الفروق ولصـالح الاختبـار ألبعدي ـ ويرى الباحث إن هذا التطور حصل بسبب حصل بسبب تكرار التدريب ممـا اثر على الجهاز التنفسي من خـلال زيارة تبادل الغاز ات وزيادة مستوى التهوية الرئوية (( يصاحب النشاط الرياضي زيادة تبادل الغاز ات نظراً لاستهلاك المو اد العضوية في الجسم لإنتاج الطاقة ـ وبالتالي إلى زيـادة قدرة الثـر ايين الرئويـة لأداء عملها

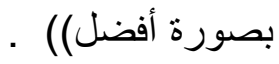

ومن الجدول (ع ) كذلك نلاحظ إن الوسط الحسبي الانحر اف المعياري لعدد مر ات النبض في وقت

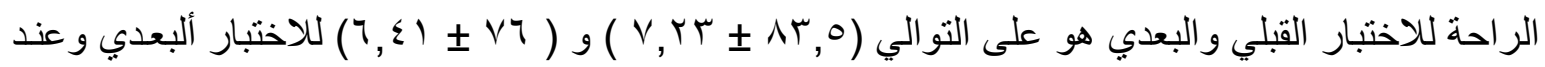

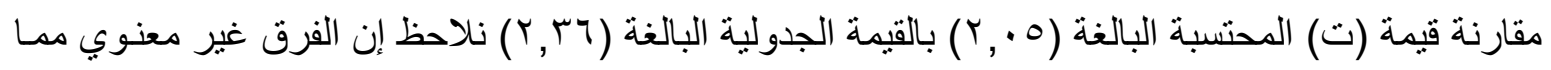
يدل إلى عدم حدوث تطور بهذا المتغير .

جدول (•)يوضح المعالم الاحصائية للاختبارين القبلي والبعدي للمتغيرات الفسيولوجيةتلمجموعة التجريبية

\begin{tabular}{|c|c|c|c|c|c|c|c|}
\hline \multirow{2}{*}{ الاحصائية } & \multirow{2}{*}{ قالجدة تية } & \multirow{2}{*}{ قالمتسبة ت } & \multicolumn{2}{|c|}{ الاختبار ألبعدي } & \multicolumn{2}{|c|}{ الاختبار القبلي } & \multirow[b]{2}{*}{ الفتغيولــرات } \\
\hline & & & $\varepsilon \pm$ & س- & $\varepsilon \pm$ & س- ا & \\
\hline معنوي & \multirow{5}{*}{$r, r 4$} & $r, Y$ & $1,0$. & $r \Psi, T Y$ & 1,19 & $r q, r v$ & الجها م/د التفس بعد \\
\hline معنوي & & $r, \wedge 1$ & $1, r 4$ & 104 & $V, O Y$ & 175 & الد النبض بعد \\
\hline معنوي & & Y, & $r,{ }^{\prime \prime \Lambda}$ & $1 r r$ & $7, \leqslant 4$ & 149 & الجه النبض بعد \\
\hline معنوي & & $r, \cdot 9$ & r,A & $11 v, 0$ & $v, 71$ & TrV & النبض بدمن الجهد \\
\hline معنوي & & $r, r 1$ & $1,7 \mathrm{~V}$ & $11 \cdot, 0$ & $V, \xi Y$ & TY. & عد النبض بـد \\
\hline
\end{tabular}




\begin{tabular}{|c|c|c|c|c|c|c|}
\hline & & & & & & الجها \\
\hline معنوي & $r, r)$ & 1,74 & $1 \cdot r$ & $\checkmark, \wedge r$ & $11 \%$ & 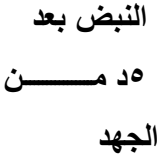 \\
\hline معنوي & $Y, Y Y$ & $\Lambda, T V$ & $1 \leqslant q, \sqrt{ }$ & $1 Y, \xi \cdot$ & D & لثنــاط إنـزيم \\
\hline
\end{tabular}

ومن الجدول (0) نفسه نلاحظ أيضا إن الوسط الحسابي والانحر اف المعياري لعدد مرات التنفس بعد

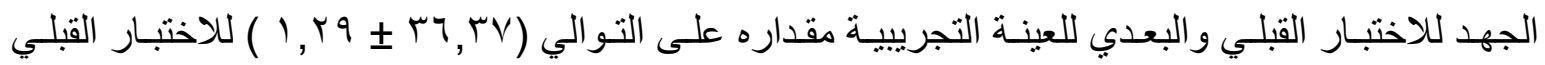

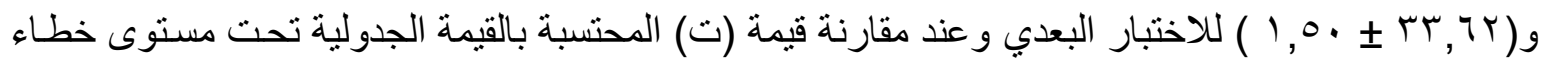
ودرجـة حريـة (V) نلاحظ إن قيمـة (ت) المحتسبة اكبر مـن القيمـة الجدوليـة ممـا يـل على معنويـة الفروق ولصالح الاختبار البعدي، ويرى الباحث ذللك بسبب زيادة عمق التنفس على حساب عدد مرات التنفس ممـا أدى إلى نقصان عدد مرات التنفس بالاتجاه الايجابي بسبب أداء الرياضي لمجهود عالي الثدة .

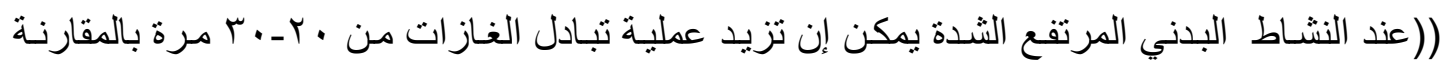
بوقت الراحـة ويرتبط ذلك بزيـادة حجم الرئتين في الرياضيين ممـا يؤدي إلى زيـادة مسـاحة الحويصـلات الهو ائيسة والتي نؤدي إلى زيـادة مقطع الثـر ايين المغذيـة ))1 ـ ومن الجدول (0) نلاحظ إن القيم المحسوبة

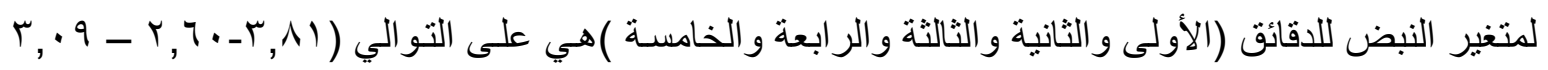

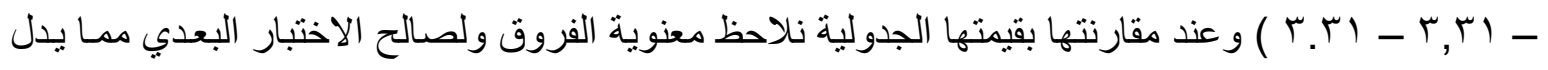
على فاعلية البرنامج التدريبي لتطوير الإمكانيات الفوسفاتية اللاهوائية ويرى الباحث إن هذا الفرق المعنوي لمتغير النبض خلال الدقائق الخمس الأولى بعد الجهد بسبب قدرة الجسم على التكيف للمجهود البدني وقدرتــ الته على استعادة الثفاء في الفترة (( إن معدل ضربات القلب لمتسابقي الفعاليات الهو ائية تقل عند الدقيقة الخامسـة تقريبا بعد الانتهاء من الجهد لا يقل عن ( •0) ضربة في أقصى معدل ضربات القلب إثناء الأداء )) 2. إما ما يتعلق بنشاط إنزيم الكرياتين كاينيز ( CK ) فنلاحظ من خلال الجدول (ع) حيث كان الوسط

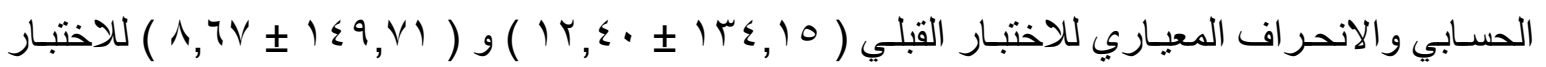

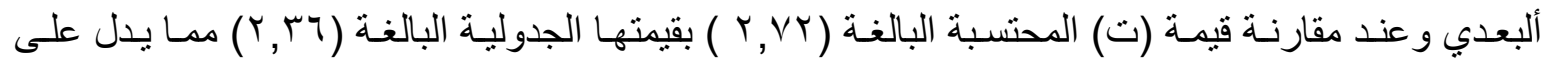
معنوية الفرق في نشاط الأنزيم وهذا ما نلاحظه في الفرق المعنوي لنتائج اختبار عدو (•0) متر والذي يدل

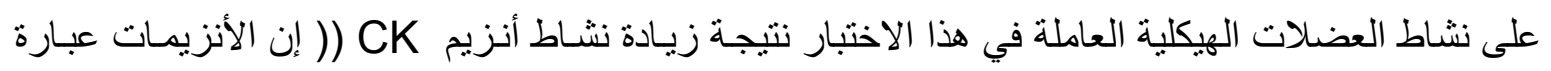
عن بروتينات تسرع التفاعلات الكيميائية في الأجهزة الحيويـة فجميع التفاعلات الكيميائية للخلايـا الحيـة قد تحدث ببطء شديد بدون الإنزيمات ))1 . ويعزي الباحث إن إنزيم ( CK ) هو احد هذه الإنزيمات التي تساعد على تفكيك أواصر الفوسفاجين للحصول على الطاقة وكما في المعادلة الآتية :

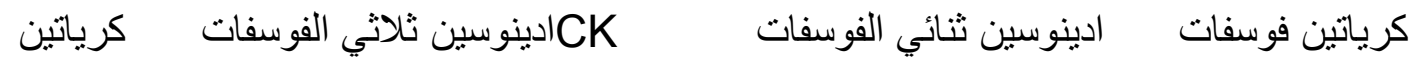


C + ATP

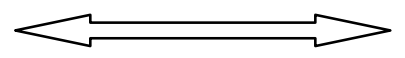

ADP

$+\quad$ C-P

r-r ع عرض نتائج الاختبارين القبلي والبعدي للمجموعة الضابطة لزمن عدو ( •) متر .

جدول (•)يوضح المعالم الاحصائية للاختبارين القبلي والبعدي لزمن عدو ( • () مترللمجموعة الضابطة

\begin{tabular}{|c|c|c|c|c|c|c|c|}
\hline \multirow{2}{*}{ الاحلائية } & \multirow{2}{*}{ قالجدة ت } & \multirow{2}{*}{ قالمحة ت } & \multicolumn{2}{|c|}{ الاختبار ألبعدي } & \multicolumn{2}{|c|}{ الاختبار القبلي } & / الاختبار / / \\
\hline & & & $\varepsilon \pm$ & س- & $\varepsilon \pm$ & 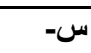 & \\
\hline غنير & $r, r 4$ & $1, \cdot V$ & $\cdot, 1 r$ & 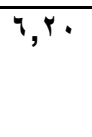 & $\cdot$, ए & $7, \Gamma \xi$ & زمن عداث \\
\hline
\end{tabular}

من الجدول (0) نلاحظ إن الوسط والانحر اف المعياري لزمن عدو ( •0) منز للاختبار القبلي والبعدي

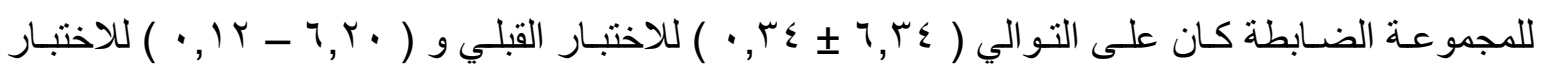

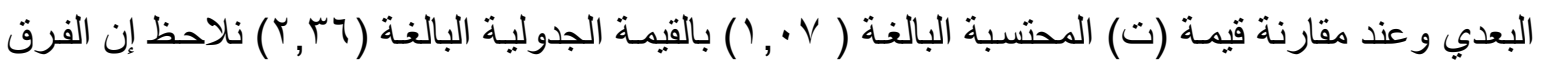
غير معنوي مما يدل على عدم فاعلية البرنامج ويرى الباحث إن البرنـامج التدريبي الذي خضعت إليه العينة

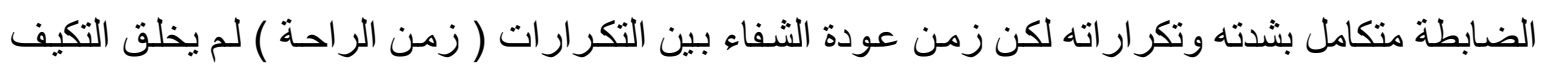
المناسب الذي يؤدي إلى تطوير الأجهزة الوظيفية .

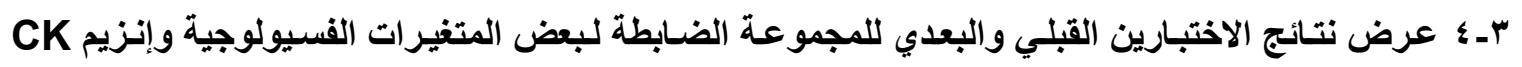
ومن الجدول (T) أيضا نلاحظ إن الوسط الحسابي والانحر اف المعياري لمتغير التنفس في الراحة للاختبار

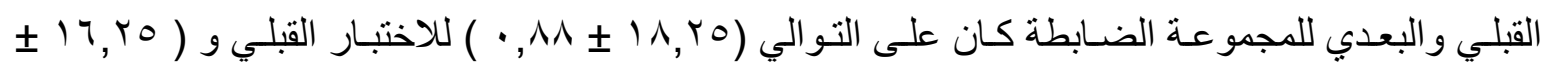

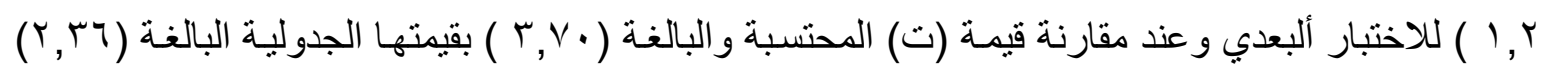
كان الفرق معنوي ولصالح الاختبار ألبعدي ويرى الباحثان إن معنوية الفرق يعزي إلى التكيف الحاصل في

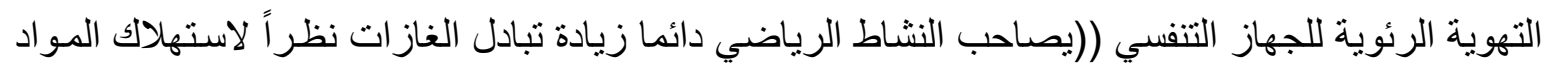

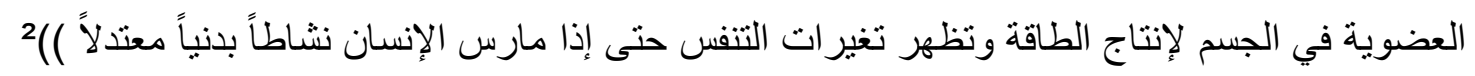
ونلاحظ إن متغير التنفس بعد الجهد من الجدول نفسـه فكان الوسط الحسـابي والانحر اف المعياري للاختبار القبلي للمجموعة الضابطة على التوالي ( مقارنة (ت) المحتسبة البالغة (^乞 , ا ) بقيمتها الجدولية نلاحظ إن الفرق غير معنوي مما يدل على عدم فاعلية البرنامج التدريبي لهذا المتغير و الذي لم يؤدي إلى تكيف الأجهزة على العمل بعد الجهد رغم ظهور فروق تذكر لكنها لم ترتقي إلى مستوى المعنوية . من خـلال (T) نلاحظ إن الوسط الحسبي و الانحر اف المعياري لمتغير النبض في الراحة للاختبار

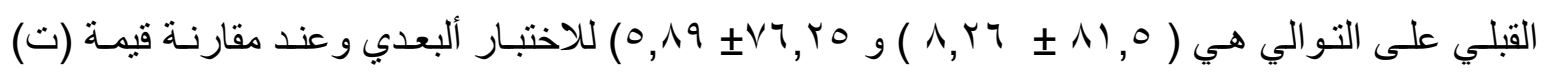




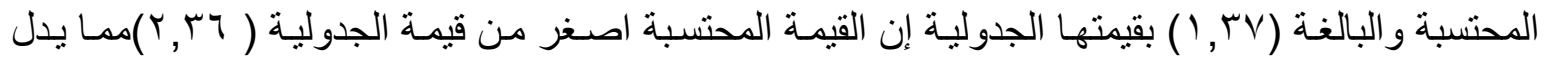
على عدم معنوية الفروق . ملك

جدول (†) يوضح المعالم الاحصائية للاختبارين القبلي والبعدي للمتنيرات الفسيولوجية للمجموعة الضابطة

\begin{tabular}{|c|c|c|c|c|c|c|c|}
\hline \multirow{2}{*}{ الاحصائية } & \multirow{2}{*}{ قالجيمة ت } & \multirow{2}{*}{ قالمحتسةت } & \multicolumn{2}{|c|}{ الاختبار ألبعدي } & \multicolumn{2}{|c|}{ الاختبار القبلي } & \multirow{2}{*}{ 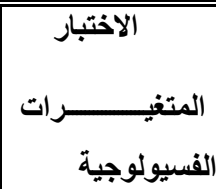 } \\
\hline & & & $\varepsilon \pm$ & س- & $\varepsilon \pm$ & س- & \\
\hline معنوي & $Y, r 4$ & $r, v$. & 1,17 & 18,40 & $\cdot, \wedge \wedge$ & $1 \Lambda, Y^{\prime}$ & الراحة م/د التـس فــــي \\
\hline غير معنوي & & $1, \leqslant 1$ & $r, \leqslant V$ & $r \leqslant, 1 Y$ & $r, r \wedge$ & $r 0,0$. & 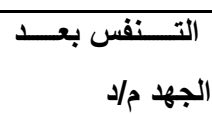 \\
\hline غير مغنوي & & $1, r v$ & 0,19 & Vฯ, ro & $\Lambda, Y^{4}$ & $11,0$. & 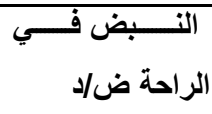 \\
\hline غير مغنوي & & $1, r \mu$ & 11,01 & $19 .$. & $1 \cdot, 9$. & $171, \cdots$ & النـ الجهر بعـا \\
\hline غير مغنوي & & $T, Y v$ & $\Lambda, \xi 1$ & $1+4,10$ & $\Lambda, \Delta r$ & $1 \leqslant r, 0$. & 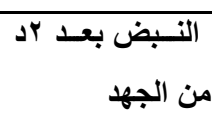 \\
\hline غير مغنوي & & $1, r V$ & $\Lambda, v_{0}$ & IYr, , & $\Lambda, 1 \mu$ & $1 Y \wedge, \vee 0$ & 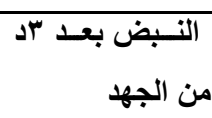 \\
\hline معنوي & & 5,70 & Y. .1 & $11 r, 0$. & 8,19 & $|r|, \cdots$ & 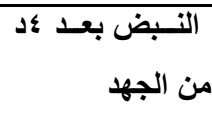 \\
\hline معنوي & & $r, v 1$ & $r, q$. & $1 \cdot 1, \cdots$ & $V, \varepsilon v$ & $117, \cdots$ & 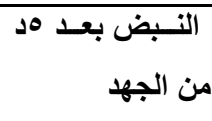 \\
\hline غير مغنوي & & $\cdot, 44$ & $1 \leqslant, r_{0}$ & $1 \cdot 0, \leqslant \pi$ & $r \cdot, 90$ & $1 \cdots, 90$ & وحدة / لتر \\
\hline
\end{tabular}

إما بالنسبة لمتغير النبض ، فمن خلال الجدول نفسه نلاحظ إن النبض للثلاث دقائق الأولى بعد الجهد

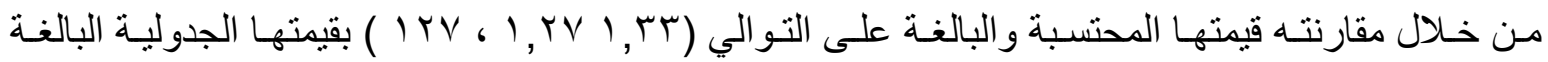

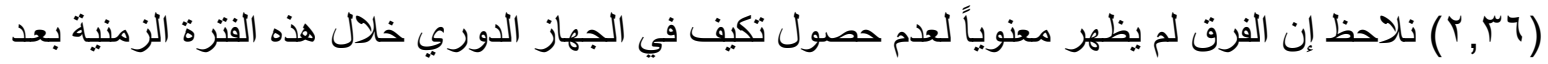
الجهد مباثـرة لوجود نقص في كميـات الأكسجين المستخدم بسبب الدين الاوكسـيني الحاصل في الخلايـا العضلات العاملة .((لا يحدث تغيرات في الجهاز ألدوراني بالجهد البدني المرتبط بالجهاز العصبي والذي

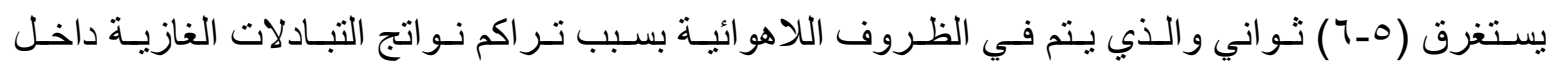
(العضلة) () 
ومن خلال الجدول ( T) نلاحظ إن الوسط الحسـابي و الانحر اف المعياري لمتغير النبض في الدقيقة

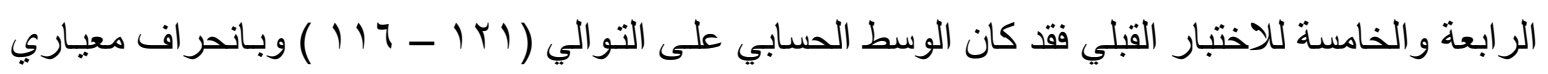

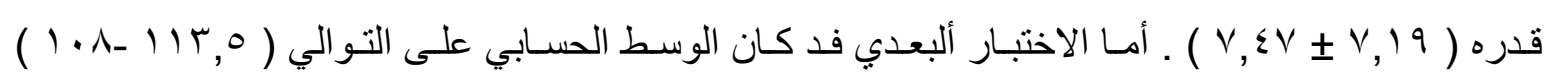

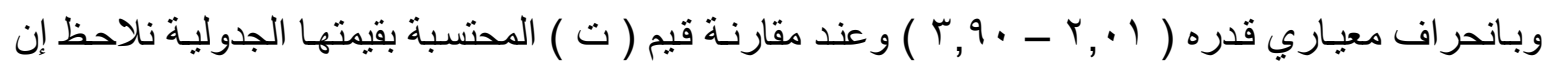

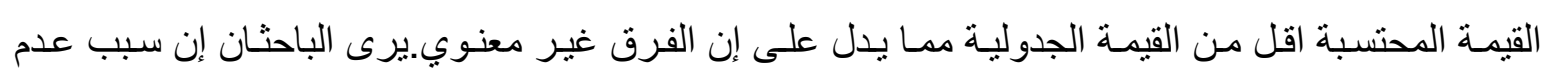

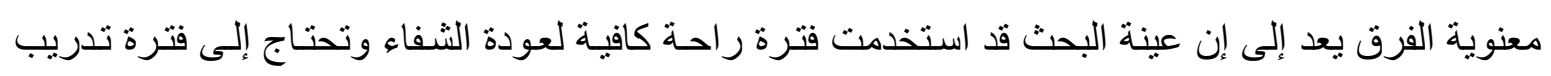

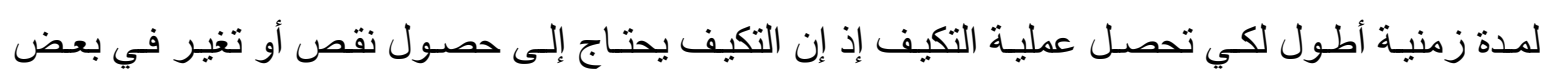
الأجززة الوظيفية مما يدفع إلى التكيف على هذا الوضع الجديد وبالتالي حصول التطور (( إذا تم تكرار

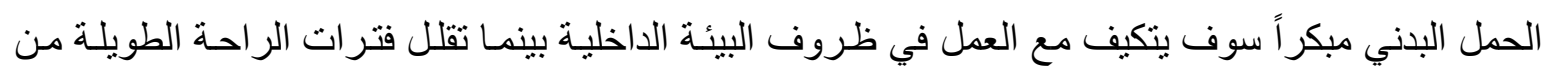

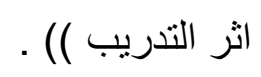

بـه عرض نتائج الاختبارين البعيدين للمجموعتين الضابطة والتجريبية لزمن عدو( • ()م

جدول (V)يوضح المعالم الاحصائية للاختبارين البعديين لزمن عدو (• ( ) متر للمجموعتين الضابطة والتجريبية

\begin{tabular}{|c|c|c|c|c|c|c|c|}
\hline \multirow{2}{*}{ الاحصائية } & \multirow{2}{*}{ 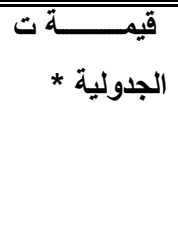 } & \multirow{2}{*}{ قالمتسبة } & \multicolumn{2}{|c|}{ المجموعة التجريبية } & \multicolumn{2}{|c|}{ المجموعة الضابطة } & \multirow{2}{*}{ الاتجار } \\
\hline & & & $\varepsilon \pm$ & س- & $\varepsilon \pm$ & س- & \\
\hline مغنوي & $r, r 4$ & $\varepsilon$, & $\cdot, 11$ & $\theta, \wedge$. & $\cdot, Y 4$ & $\curlyvee, Y \cdot$ & 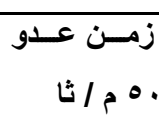 \\
\hline
\end{tabular}

قيمة (ت) الجدولية إمام درجة حرية (ن- إن ) وعند مستوى خطأ ه •, .

من الجدول ( V) و الذي يوضـح الاختبـار ات البعديـة للعينتين الضـابطة و التجريبيـة نلاحظ إن الوسط

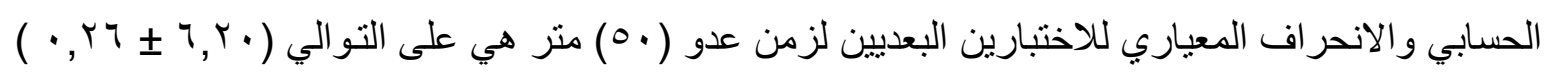

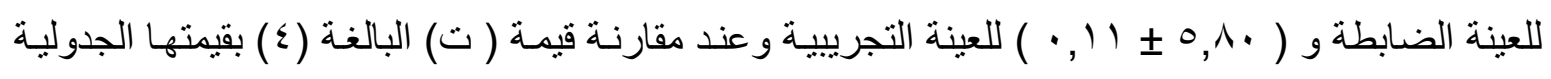

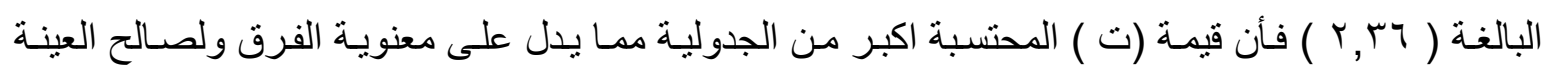

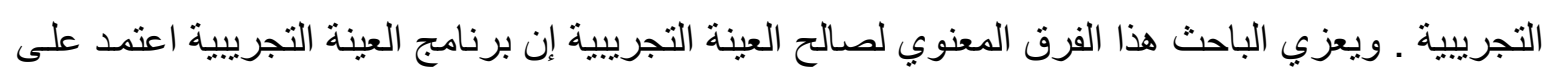

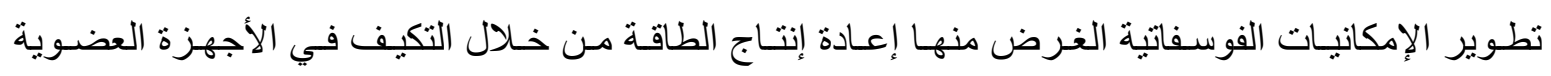
و الوظيفية بساطة النقص في كمية الراحة البينية بين التكرارات في عودة النبض ـ (( إن التكيف في مجال التدريب الرياضي تتوقف عليه العملية التدرييية بكاملها نتيجـة وقوع أجهزة الجسم الداخلية للرياضسي تحت تأثير حمل بدني مقنن وان هذه الأجهزة تتكيف مع هذا الحمل وترفع من قدرة اللاعب لتحمل أحمال كبيرة))

rــ عرض نتائج الاختبـارين البعديين للمجموعتين الضـابطة والتجريبيـة لبعض المتغيرات الفسيولوجية

وأنزيم (CK) 
جدول (^) يوضح المعالم الاحصائية للاختبار ألبعدي للمتغيرات الفسيولوجية للمجموعتين التجريبية والضابطة

\begin{tabular}{|c|c|c|c|c|c|c|c|}
\hline \multirow{3}{*}{ الاحصائية } & \multirow{3}{*}{ قالجدولية } & \multirow{3}{*}{ قيمة ت } & \multicolumn{2}{|c|}{ المجموعة التجريبية } & \multicolumn{2}{|c|}{ المجموعة الضابطة } & \multirow[b]{3}{*}{ المتغيرات الفسيولوجية } \\
\hline & & & $\varepsilon \pm$ & 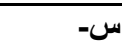 & $\varepsilon \pm$ & 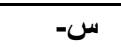 & \\
\hline & & & & & & & \\
\hline غير مغنوي & \multirow[t]{10}{*}{$r, r 4$} & $1, \wedge \wedge$ & $1,1 Y$ & $10,1 Y$ & 1,14 & 17,50 & التنفس في الراحة م/د \\
\hline غير معنوي & & $\cdot, \leqslant 0$ & $1,0$. & rr, & $Y, \leqslant V$ & $r \varepsilon, 1 r$ & التنفس بعد الجها م/د \\
\hline غير مغنوي & & $\cdot, \cdot v$ & $7 . \$ 1$ & $v 4, \cdots$ & $0, \wedge q$ & $\begin{array}{l}V 4, Y^{\circ} \\
\end{array}$ & النبض في الراحة ض/د \\
\hline غير مغنوي & & 1,7 & 1,47 & $104, \cdots$ & 11,01 & 17. & النبض بعد اد من الجها \\
\hline غير مغنوي & & 1,14 & $r, r \Lambda$ & Irr,.. & $\Lambda, \leqslant 1$ & $1 \% 4, V$ & النبض بعد זد من الجها \\
\hline غير مغنوي غ غ & & 1,01 & $r, \wedge 1$ & $11 v, 0$. & $\Lambda, v_{0}$ & TrT & النبض بعد "آد من الجها \\
\hline غير مغنوي غ & & $r, .4$ & $1,7 \mathrm{~V}$ & $11 \cdot, 0$. & $r, \cdot 1$ & $11 \%, 0$ & النبض بعد عد من الجها \\
\hline معنوي & & $r, 1 r$ & 1,74 & $1 \cdot r, \cdots$ & $r, q$. & $1 \cdot 1$ & النبض بعد هد من الجها \\
\hline معنوي & & 7,99 & $\Lambda, T V$ & $1 \leqslant q, v 1$ & $1 \leqslant, \mu_{0}$ & $1 \cdot 0,4$ & نشاط إنزيم CK وحدة /لتر \\
\hline & & & & & & $r$ & \\
\hline
\end{tabular}

نلاحظ في الجدول (^) بالنسبة لمتغير التنفس في وقت الراحة بعد الجهد البدني نلاحظ من خلال مقارنة قيمـة

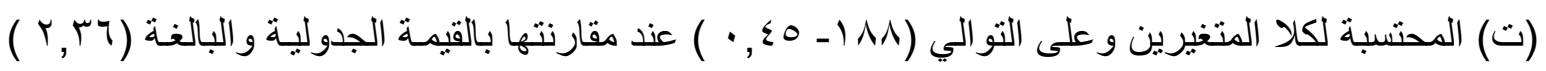
نلاحظ إن القيمة الجدولية البالغة (T, Y ) نلاحظ إن القيمـة الجدوليـة اكبر من المحتسبة ممـا يدل على عدم معنويـة الفروق بين العينتين الضـابطة والتجريييـة وعدم اختلاف تأثير البرنـامجين عن مقارنتهـا في هذين

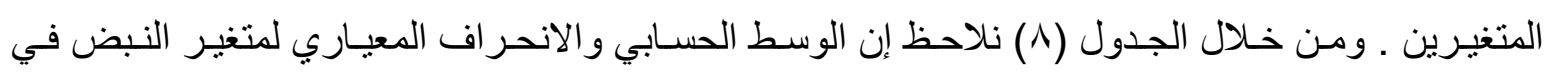

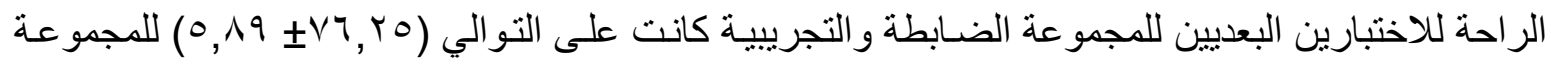

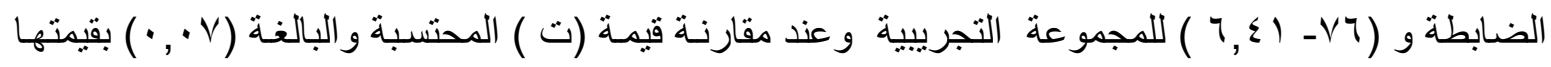

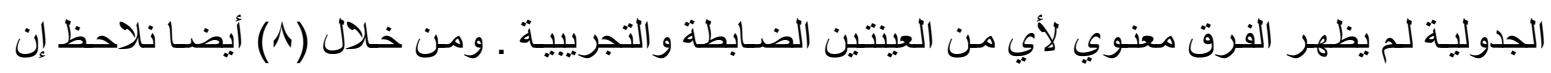
متغير النبض خـلال ثـلاث دقائق التي بعد الجهد البدني و عند مقارنـة عدد مر ات النبض للعينتين الضـابطة و التجريبية من خلال القيمة المحتسبة بقيمتها الجدولية نلاحظ إن الفرق غير معنوي لهذه الدقائق الثناث مما يدل على تساوي تأثثر البرنامجين المطبقين على العينة الضابطة والتجريبية وعدم تأثيرهم في الجهاز الدوري وان الفرق الإحصـائي الذي ظهر لم يرنق للمستوى المعنوية وان الجهاز ألدور اني لكلا العينتين لم يتكيف خلال هذه الفترة الزمنية القليلة بعد الجهد. لكن نلاحظ من خلال الجدول (^) نفسه متغير النبض في الدقيقتين

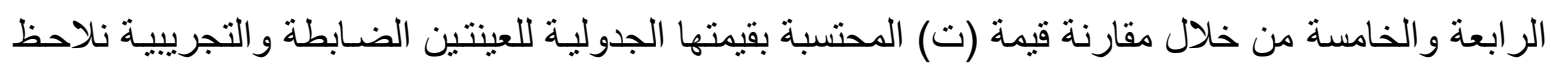
إن الفرق معنوي ولصالح العينة التجريبية وذللك باحتساب عدد مرات النبض الأقل وهذا يعني حصول التكيف للعينة التجريبية لكلا الدقيقتين الرابعة والخامسة بعد الجهد البدني ـ ويرى الباحثنان فاعلية البرنامج الفوسفاتي بلي 
اللاهو ائي في تكيف الجهاز الدوري بعد الراحة في الدقيقة الرابعـة والخامسـة وان النـاتج القلبي ازداد ممـا اثر على مر ات النبض في (( وان سر عة عودة ضربات القلب إلى حالتها الطبيعية بعد الجهد علامـة مميزة للجسم لهم الرياضي ودلالة واضحة على تطبع القلب وجهاز الدوران على الجهد الذي يتعرض لـه جسم الرياضي ))1

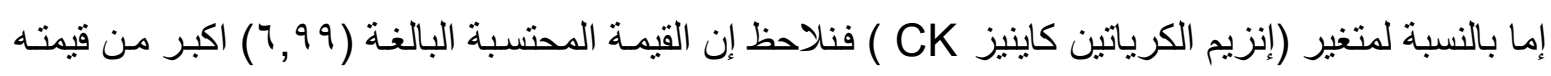

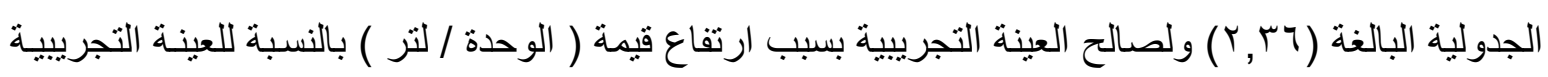

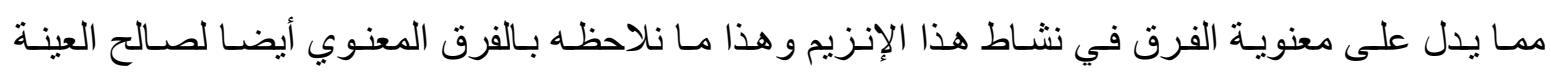
التجريبية في اختبـار عدو ( •0) متر ممـا يدل على نشـاط العضـلات الهيكلية العاملـة للعينـة التجريبيـة والتي وني تدربت في البرنامج المعد لغرض تطوير الإمكانيات الفوسفاتية للعينة التجريبية يعود بسر عة ممـا يؤدي إلى زيادة التقلصات العضلية السريعة ، إلى انه لا يعتمد نظام ( ATP - PC ) في إنتاج الطاقة على مجموعـة لإنة

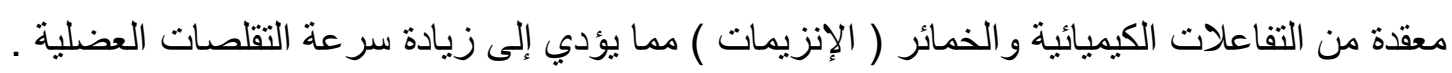

\section{ع- الاستنتاجات و التوصيات}

ع ـ 1 الاستنتاجات: من خلال تحليل النتائج ومناقتنتها توصل الباحث إلى الاستتتاجات الآتية :

أولا - المجموعة التجريبية: هـ ظهور فرق معنوي في زمن اختبار عدو •0 م لعدد مر ات التنفس في الراحة و عدد مرات التنفس بعد الجهد مما يدل على فاعلية برنامج نقص الفوسفاجين . 7- عدم ظهور فرق معنوي لمعدل ضربات النبض في الراحة مما يدل عدم فاعلية برنامج الفوسفاجين . V- ظهور فرق معنوي في الخمس دقائق الأولى بعد الجهد البدني مما يدل على فاعلية نقص الفوسفاجين

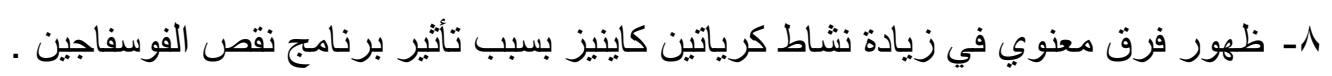

\section{ثانياً : المجموعة الضابطة :}

V- عدم ظهور فرق معنوي لزمن اختبار عدو •0 م مما يدل عدم فاعلية برنامج المجموعة الضابطة . ^ـ ظهور فرق معنوي في عدد مرات التنفس في وقت الراحـة ممـا يدل على فاعلية برنـامج المجموعـة الضابطة تجاه هذا المتغير . 9ـ عدم ظهور فرق معنوي في عدد مرات التنفس في الدقيقة بعد الجهد و في وقت الراحة مما يدل على عدم تكيف المجمو عة الضابطة . • ا ـ عدم ظهور فرق معنوي في عدد مرات النبض للثلاث دقائق الأولى بعد الجهد ممـا يدل على عدم تكيف المجمو عة الضابطة .

11 - ظهور فرق معنوي في عدد مرات ( النبض في الاقيقة ) للدقيقتين الرابعة و الخامسـة بعد الجهد ممـا يدل على تكيف المجمو عة الضابطة لهذه الفترة من الجهد . rا - عدم ظهور فرق معنوي في نشاط إنزيم كرياتين كاينيز ( CK) مدا يدل على عدم فاعلية البرنـامج لهذا المتغير . 
ثالثا ــ أظهرت نتائج المقارنة بين المجموعتين الضابطة والتجريبية الاتي :

ا ـ ظهور فرق معنوي في زمن انجاز عدو • مم بين المجموعتين الضابطة والتجريبية ولصالح التجريبية . ז- عدم ظهور فروق معنويـة بعدد مـرات التنفس في وقت الراحـة وبعد الجهد البدني بين المجمو عتين الضابطة و التجريبية ولصالح التجريبية . r- عدم ظهور فروق معنوية في عدد مرات ( النبض في الاقيقة ) في وقت ( الراحة بعد الجهد ) مباشرة وللاقيقة الأولى والثانية والثالثة بين المجموعتين الضابطة والتجريبية ولصالح التجريبية . عـ ظهور فرق معنوي في عدد مـرات ( النبض في الدقيقة ) للدقائق الرابعـة والخامسـة ببين المجمو عتين الضابطة التجريبية ولصالح المجموعة التجريبية . 0ـ ظهور فرق معنوي في نشاط إنزيم كرياتين كاينيز (CK) بين المجمو عتين ولصالح التجريبية .

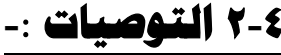

ا ـ من خلال الدراسة التي أجر اها الباحث و الاستتناجات التي توصل إليها يوصي بالاتي : r - تدريب لاعبي السرعة بتمرينات نقص الفوسفاجين لتطوير زمن انجاز عدو ( • (0) م .

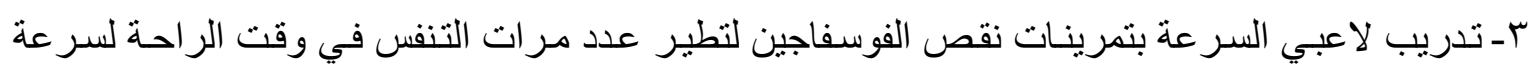
عودة الاستشفاء بعد الجهد . ع ـ ـ تدريب لاعبي السرعة بتمرينـات نقص الفوسفاجين لتحسين عدد مرات ( النبض في الدقيقة ) وللخمس دقائق الأولى بعد الجهد ( سرعة عودة الثفاء ) .

هـ التدريب بنقص الفوسفاجين يزيد من نشـاط إنزيم كرياتين كاينيز ( CK ) من اجل عمل نظام الطاقة ( . ( ATP-PC

ج- يجب على المدربين العمل على تقنين الوحدة التدريبيـة مـن اجل الوصـول إلى هدف الوحدة التدريبيـة وخاصة فيما يتعلق بعودة الثفاء . V- إجر اء دراسة مشابهة على الأعمار المختلفة الأخرى من لاعبي الساحة و الميدان ولكلا الجنسين .

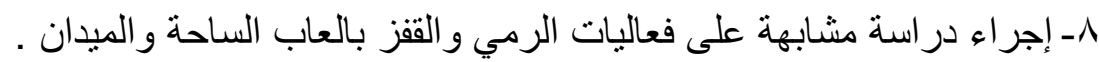
9 - إجر اء دراسة مشابهة على الفعاليات الأخرى الفردية و الجماعية . 
9 9. شاكر فرهود الدرعة ، علم التدريب الرياضي ، ط1 ، منشورات ذات السلاسل الكويت ، 1991 ـ .

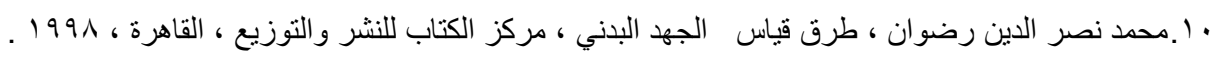

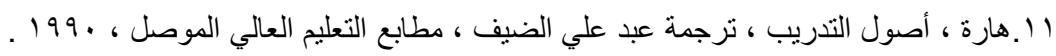

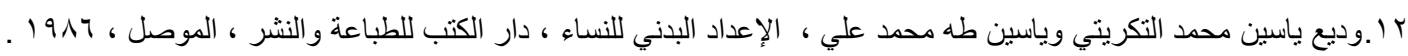

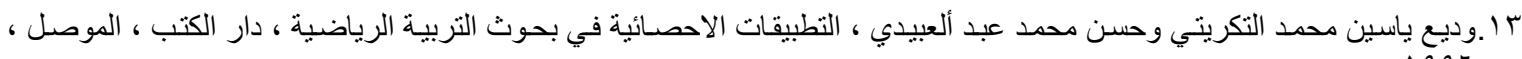

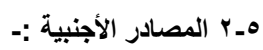

1. Lehimger, Biochemistry Textbook, $2^{\text {nd }}$ Ed., New York, 1975. 2.

Albert $\mathrm{L}$. Fox, Donald K., Mathews, The physiology basic of physical education and athletics, Samdersco college publishing , 1981.

3.

Fox, Donald, K. Mathews, Interval training conditioning for sport and general fitness , 1974 .

Edward, L.

\section{الملاجق}

الملحق (' ('Creatine - Kinase

الإجراءات

فصل الام : (1) n

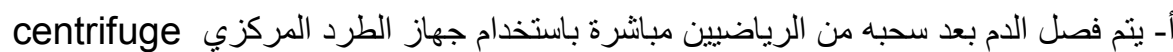

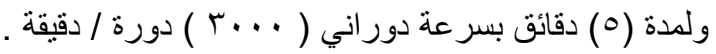

$$
\text { ا }
$$

بعد عملية الفصل يتم نقل السيروم ( مصل الدم ) في أنابيب خاصة مرقمه حسب رقم اللاعب ونوع العينة ثم ينم حفظ

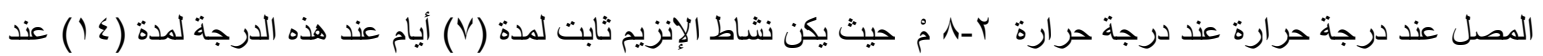
درجة لمدة (ع ا) عند درجة حرارة ( •rץْ) .

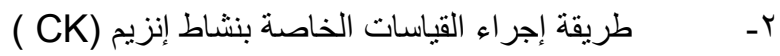

تم استخدام سيت قياس عالمي RADOX CREATINE KINASE KIT (ENGLAND)

يحتوي سيت الفحوصات على كو اشف متعددة : ا ـ محلول قياسي قاعدي ( Buffer glucose ) يعمل فيه الإنزيم .

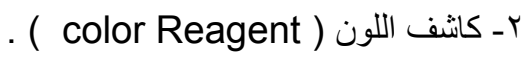

r HCl $0.1 \mathrm{~N}$

ع - إنزيم CK قياس محايد بنشاط قياس ( U/L 205 ) .

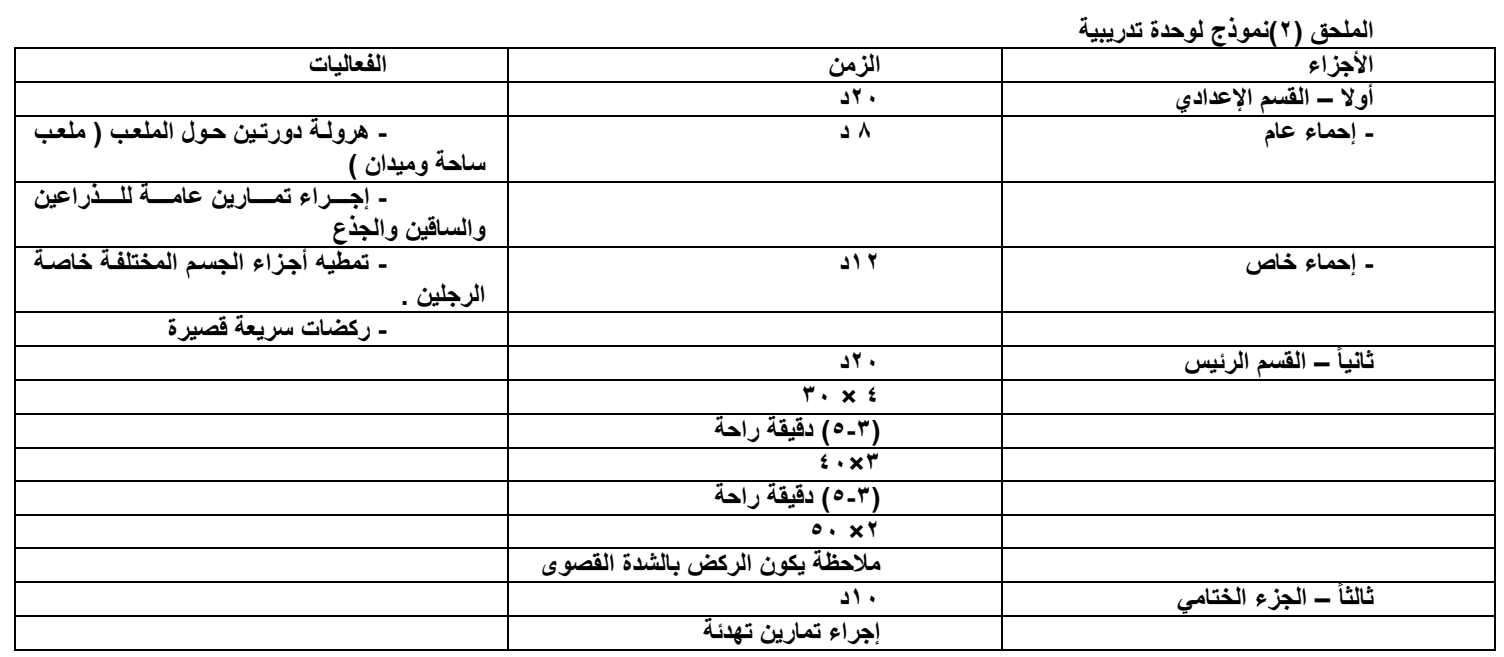

